\title{
Diagnostic Value of Serum Neuron-Specific Enolase Level in Patients With Acute Ischemic Stroke; A Systematic Review and Meta-Analysis
}

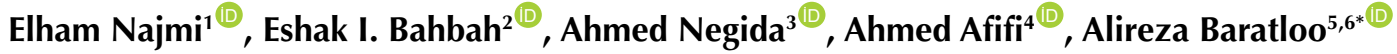 \\ ${ }^{1}$ Department of Emergency Medicine, Faculty of Medicine, Shahid Beheshti University of Medical Sciences, Tehran, Iran \\ ${ }^{2}$ Faculty of Medicine, Al-Azhar University, Damietta, Egypt \\ ${ }^{3}$ Faculty of Medicine, Zagazig University, EL-Sharkia, Egypt \\ ${ }^{4}$ Medical Research Center, Faculty of Medicine, Ain Shams University, Cairo, Egypt \\ ${ }^{5}$ Prehospital and Hospital Emergency Research Center, Tehran University of Medical Sciences, Tehran, Iran \\ ${ }^{6}$ Department of Emergency Medicine, Sina Hospital, Tehran University of Medical Sciences, Tehran, Iran
}

\begin{abstract}
Background: We aim to assess the predictive value of serum neuron-specific enolase (NSE) level in patients with acute ischemic stroke referring to the emergency department.

Methods: This systematic review and meta-analysis performed, considering the PRISMA and MOOSE statement guidelines. A computerized literature search of the known medical database conducted by using the relevant keywords. We included studies published before November 2016 in which stroke patients compared with non-stroke controls and also studies evaluating the serum levels of NSE in the study groups. Statistical analysis was pooled in a random effect model analysis using the Comprehensive Meta-Analysis software.

Results: We included 12 articles in the qualitative and quantitative analysis, that their quality acceptable based on the Newcastle Ottawa Scale (NOS scale). The pooled effect estimates showed that NSE is significantly higher in ischemic stroke patients in comparison with their controls with a high effect estimate [OR 9.68, 95\% Cl (3.06 to 30.6)]. The effect estimate remained statistically significant under the fixed and random effects model.

Conclusion: Our results show higher levels of NSE in patients with stroke than in the control group, indicating that NSE plays a role in the diagnosis of stroke. In terms of prognosis, there is evidence regarding the direct and indirect relationship; and it founded that serum levels of NSE is higher in larger stroke volume, which needs further research.

Keywords: Ischemia; Meta-analysis; Phosphopyruvate hydratase; Predictive value of tests; Stroke
\end{abstract}

Citation: Najmi E, Bahbah El, Negida A, Afifi A, Baratloo A. Diagnostic value of serum neuron-specific enolase level in patients with acute ischemic stroke; a systematic review and meta-analysis. Int Clin Neurosci J. 2019;6(2):36-41. doi:10.15171/icnj.2019.08.

*Correspondence to

Alireza Baratloo; Department of Emergency Medicine, Sina Hospital, Hasanabad Square, Tehran, Iran.

Tel: +989122884364; Email: arbaratloo@sina.tums. ac.ir, alirezabaratloo@yahoo. com

Published online June 292019

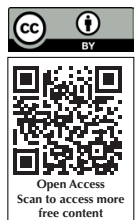

\section{Introduction}

Acute ischemic stroke is one of the severe diseases, considering the fifth leading cause of mortality and morbidity in the United States. It reported that 1 of every 20 persons is dying due to this disease, and every 4 minutes, someone dies due to stroke. ${ }^{1-4}$ Timely diagnosis results from proper history taking and neurological examinations, but still, there is an active role for paraclinical and radiological evaluation so can make the diagnosis, prognosis, and outcome prediction..$^{5-9}$

Investigations have been conducted to assess the probable role of serum biomarkers for various aspects of stroke subject, from diagnosis to outcome prediction, and research is still on. Neuron-specific enolase (NSE) is the one, probably taken into consideration more than the others. It is a glycolytic catalyze enzyme, present in neuronal, neuroendocrine tissues, and cerebrospinal fluid (CSF). ${ }^{10}$ Kansal et al reported that its measurement in CSF might assist in the diagnosis of neurodegenerative diseases, such as Creutzfeldt-Jacob and ischemic stroke. ${ }^{11}$ Recently, studies provide evidence regarding the possible correlation between ischemic stroke and elevation of serum NSE. ${ }^{12-14}$ Anand et al. investigated time to increase the serum level of NSE in the case of middle cerebral artery occlusion. ${ }^{15}$ Singh et al reported that NSE level is significantly high in patients with severe neurological deficit than the groups of mild or moderate. ${ }^{16}$ Besides, the study of Lu et al demonstrates that after treatment of ischemic stroke, there is a strong correlation between the reduction of NSE serum level and good prognosis. ${ }^{17}$

It seems that the role of serum biomarkers, including NSE, for diagnosis of stroke has been previously taken into account; but it is still vague. In this systematic review and meta-analysis, we aim to assess the diagnostic value of serum NSE level in patients with acute ischemic stroke, to weigh whether its level could consider as a diagnostic factor or not?

(C) 2019 The Author(s). This is an open access article distributed under the terms of the Creative Commons Attribution License (http:// creativecommons.org/licenses/by/4.0/), which permits unrestricted use, distribution, and reproduction in any medium, provided the original work is properly cited. 


\section{Methods}

This systematic review and meta-analysis performed during 2017 with a team from Iranian and Egyptian researches. We followed the Preferred Reporting Items for Systematic Reviews and Meta-Analyses (PRISMA) and Meta-analysis of Observational Studies in Epidemiology (MOOSE) statement guidelines during the preparation of this systematic review and meta-analysis. ${ }^{18,19}$ All steps performed in line with the Cochrane Handbook of Systematic Reviews and Meta-analysis of interventions and all analyses were performed in line with the equations recommended by Borenstein et al in the introduction to meta-analysis. ${ }^{20,21}$

\section{Literature Search Strategy}

A computerized literature search of the known medical database of PubMed, EMBASE, ISI Web of Sciences, CINAHL and Scopus using the following keywords: ((Phosphopyruvate Hydratase) OR (Neuron Specific Enolase)) AND "Stroke"). We included studies published in English before November 2016 in which stroke patients compared with non-stroke controls and also studies evaluating the serum levels of NSE in the study groups.

\section{Study Selection}

Two authors independently screened the literature search results for relevant studies. All studies published before November 2016 included. In the first step, titles and abstracts of the retrieved records screened, and then full-text articles of selected papers at the first step were evaluated. Any disagreement between the two reviewers resolved by discussion with a third reviewer.

\section{Eligibility Criteria}

(1) Studies whose population was patients with stroke compared with non-stroke controls; (2) studies evaluating the serum levels of NSE in the study groups; (3) studies that were described as observational studies, whether prospective or retrospective, evaluating NSE in stroke and non-stroke patients. We excluded animal studies and also studies whose data were not reliable for analysis.

\section{Data Extraction}

Data were extracted independently by 2 reviewers to a uniform data extraction sheet. The extracted data includes (1) characteristics of the study design of included studies, (2) characteristics of the study population, and (3) data of the study outcomes.

\section{Risk of Bias Across Studies}

To explore the publication bias across studies, we constructed funnel plots to present the relationship between effect size and precision. Evidence of publication bias was assessed by (1) the Egger's regression test, and (2) the trim and fill method.
Synthesis of Results

The prognostic value of NSE in stroke patients presented in observational studies in different formats. Studies reported their outcomes as (1) the mean difference and variance between the stroke group and the control group, (2) correlation coefficient between NSE and stroke, or (3) binary data as odds ratios with their 95\% CI. The Cohen's (d) effect size and its variance computed from all studies according to equations provided in the Introduction to meta-analysis. Then the Cohen's (d) effect size was converted into the log point estimate (odds ratio) and its variance. Finally, the $\log (\mathrm{OR})$ and its variance were pooled in a random effect model analysis using the Comprehensive Meta-Analysis software. Heterogeneity assessed by the Cochrane Q test, chi-square test for the Q statistics distribution, and the I-square test. The trim and fill method was used to investigate small study effects and the possibility of publication bias.

\section{Results}

\section{Study Selection}

The primary literature search resulted in 1300 records, and finally, 12 articles with a total of 970 patients included in the meta-analysis. ${ }^{13,14,16,22-30}$ Of the excluded studies, there were two relevant articles (Cunningham et $\mathrm{al}^{31}$ and Wunderlich et $\mathrm{al}^{32}$ ) as they reported the effect estimates in figures whose data could not be extracted and were not reliable for analysis. The PRISMA flow diagram of the current study has shown in Figure 1.

\section{Characteristics and Quality of Included Studies}

Baseline characteristics of these studies summarized in Table 1. The quality of included studies was acceptable, according to the Newcastle Ottawa Scale (NOS).

\section{The Correlation Between NSE and Stroke}

Figure 2 shows the forest plot of the OR of NSE in stroke vs. control cases with $95 \%$ CI under the fixed and random effect models. The pooled effect estimates showed that NSE is significantly higher in ischemic stroke patients compared to their controls with a high effect estimate (OR 9.68, 95\% CI [3.06 to 30.6]). The effect estimate remained statistically significant under the fixed and random effects model.

Figure 3 shows the funnel plot of standard error by point (log) of NSE in stroke vs. control cases with the standard error of under the random effect model. It showed no evidence of publication bias. The trim and fill method gave the same effect estimate suggesting no small study effects.

\section{Discussion}

The current meta-analysis aimed to clarify whether there was any significant difference in NSE levels between stroke patients and control. Our findings show that NSE serum levels are considerably higher in stroke patients 


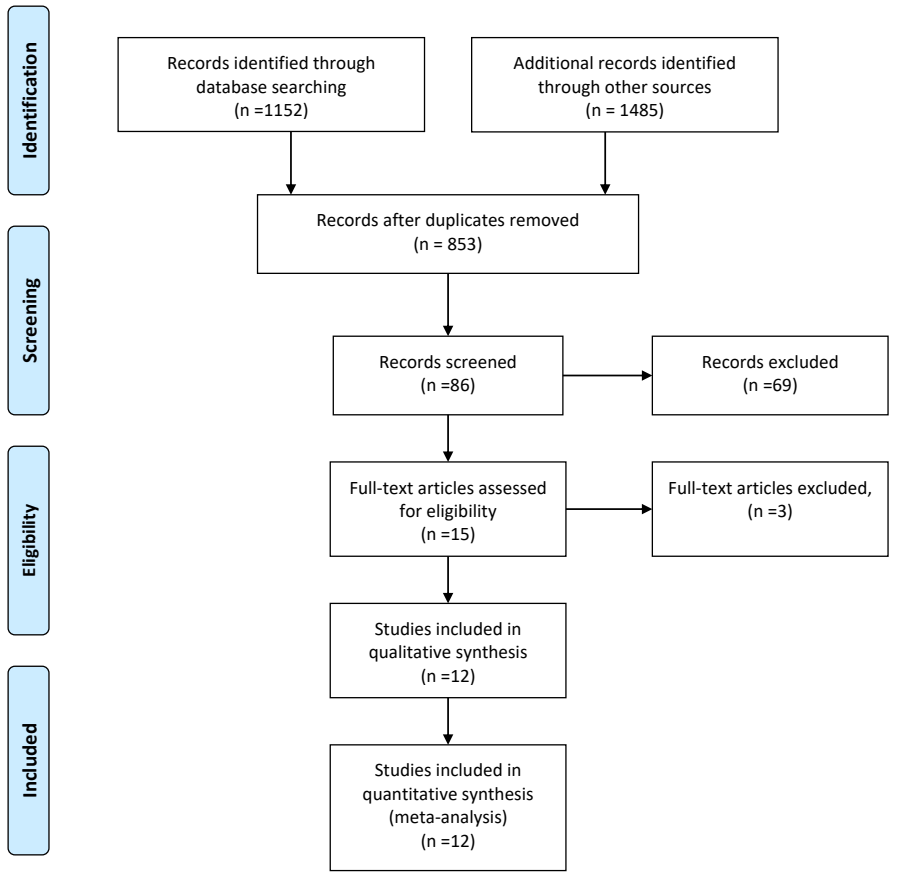

Figure 1: PRISMA Flow Diagram.

compared to their controls.

Stroke is an emergency medical condition which threatens the patient's life and causes high levels of disability and mortality all over the world. In response to stroke, brain cells produce particular changes, such as releasing specific neuronal markers into the circulation and increasing neuronal isoenzymes levels, which results in brain damage. The central nervous system insult is evaluated by several neurobiochemical markers which have a standard role in the diagnosis and management of stroke patients with neurological side effects. NSE a neuronal form of the intracytoplasmic glycolytic enzyme enolase is one of these markers. Several studies have verified that NSE can be discovered in the peripheral blood of stroke patients and could be a useful marker for acute ischemic stroke.

Likewise, the conclusion of our meta-analysis is in agreement with Anand et $\mathrm{ll}^{15}$ who conducted a systematic review in 2005 consisted of 597 patients, and reported that NSE was considerably higher in stroke patients in comparison with control. They also showed that NSE significantly correlated with infarct volume, however, it did not correlate with functional outcome, and there was no clear relationship between NSE and stroke severity. Also, a systematic review by Ahmed et $\mathrm{al}^{33}$ confirmed that NSE positively correlated with subacute infarct volume.

These results are consistent with the findings of nine out of the 12 included studies in the current meta-analysis, which showed that NSE levels were meaningfully higher in stroke patients than in the control group while, other three included studies showed no significant difference between NSE and control. ${ }^{28,34,35}$ This contrast might be explained by the slow released of NSE from damaged tissue to peripheral blood.

In terms of functional outcomes, included studies used different methods to assess functional outcomes such as Barthel index, Lindley scale, modified Rankin Scale (mRS), Glasgow Outcome Score, and activities of daily living scale. Three studies ${ }^{22,32,35}$ reported a notable correlation between NSE and functional outcome. Moreover, Pandey et $\mathrm{al}^{14}$ and Bharosay et $\mathrm{al}^{25}$ concluded that the higher the NSE level, the more significant functional worsening. However, Shahrokhi et al showed no significant difference between NSE serum concentrations and clinical outcome. ${ }^{36}$ Using different evaluation scales and the small sample size included might explain this contrast.

Nine included studies ${ }^{14,16,22-28}$ used the National Institutes of Health Stroke Scale (NIHSS) to evaluate the neurological status and stroke severity. All of them reported a notable correlation between NIHSS scores and NSE levels.

Two studies reported on NSE levels at the onset of a stroke. Oh et $\mathrm{al}^{23}$ found that the initial NSE was significantly higher in stroke patients than control within less than 24 hours. Wunderlich et al. ${ }^{32}$ with a total of 66 patients, reported that NSE levels showed a first rise 2-3 hours after onset of the first stroke symptoms, but they did not compare that with control levels.

Regarding infarct volume, four included studies ${ }^{23,28,30,32}$ demonstrated a significant correlation between NSE and infarct volume.

Brea et $\mathrm{al}^{28}$ involved patients with acute ischemia and patients with intracerebral hemorrhage and showed that 
Table 1. Summary and Baseline Characteristics of the Final Included Studies

\begin{tabular}{|c|c|c|c|c|}
\hline Reference & Methodology & Statistical Sample & $\begin{array}{l}\text { Prognosis Exploration } \\
\text { Methodology }\end{array}$ & Description \\
\hline $\begin{array}{l}\text { Butterworth } \\
\text { et al }{ }^{29}\end{array}$ & $\begin{array}{l}\text { Hospitalized patients suffering from } \\
\text { ischemic stroke were } 103 \text { that } 51 \text { of } \\
\text { them were under control }\end{array}$ & $\begin{array}{l}\text { The United Kingdom, } \\
\text { \# male: } 63 ; \text { female: } 40 \text { age } \\
\text { average: } 73.6 \text {. }\end{array}$ & $\begin{array}{l}\text { Barthel index, mRS } \\
\text { Lindley score, Infarct } \\
\text { volume }\end{array}$ & $\begin{array}{l}\text { In this study, NSE correlated with } \\
\text { ischemic stroke, but any correlation } \\
\text { between first, second, and third days did } \\
\text { not exist. }\end{array}$ \\
\hline Pandey et $\mathrm{al}^{14}$ & $\begin{array}{l}200 \text { patients suspected to ischemic } \\
\text { and } 50 \text { of them were under control }\end{array}$ & $\begin{array}{l}\text { India } \\
\text { \# male: } 82 \text { above } 21 \text { years old } \\
\text { \# female: } 38 \text { above } 21 \text { years } \\
\text { old }\end{array}$ & NIHSS & $\begin{array}{l}\text { In this study, the patient's NSE level in } \\
\text { the seventh day for the severe group was } \\
\text { higher. }\end{array}$ \\
\hline Hill et $\mathrm{al}^{22}$ & $\begin{array}{l}38 \text { patients hospitalized in } 2 \text { hospitals } \\
\text { with an ischemic stroke diagnosis }\end{array}$ & $\begin{array}{l}\text { Canada; } \\
\text { \# male: } 18 \text {, \# female: } 10\end{array}$ & NIHSS, mRS & $\begin{array}{l}\text { In this study, the NSE level for those } \\
\text { suffering from AIS was higher, and it had } \\
\text { a direct correlation with prognosis. }\end{array}$ \\
\hline Missler et $\mathrm{al}^{30}$ & $\begin{array}{l}\text { Hospitalized patients for ischemic } \\
\text { stroke check-in hospitals. }\end{array}$ & $\begin{array}{l}\text { Germany; } \\
\text { \# male: } 32, \# \text { female: } 12 \\
\text { Age average: } 65.1\end{array}$ & $\begin{array}{l}\text { CT infarct volume } \\
\text { GCS at } 6 \text { months }\end{array}$ & $\begin{array}{l}\text { In this study, NSE and CVA volume } \\
\text { correlated, but any correlation with } \\
\text { outcome was not perceived. }\end{array}$ \\
\hline Zaheer et al ${ }^{13}$ & $\begin{array}{l}75 \text { visiting patients to check AIS, } \\
\text { which approved in the second day by } \\
\text { CT scan. }\end{array}$ & $\begin{array}{l}\text { Germany; } \\
\text { \# male: } 47, \# \text { female: } 28 \\
\text { Age average: } 61.9\end{array}$ & $\begin{array}{l}\text { Arrival GCS } \\
\text { Thirtieth day mRS }\end{array}$ & $\begin{array}{l}\text { In this study, NSE correlated with GCS } \\
\text { and MRS of patients, and it is a prognosis } \\
\text { factor. }\end{array}$ \\
\hline Oh et $\mathrm{al}^{23}$ & $\begin{array}{l}109 \text { visiting patients suspected to AIS } \\
\text { that MRI approved their CVA. }\end{array}$ & $\begin{array}{l}\text { South Korea; } \\
\text { \# male: } 42, \text { \# female: } 21 \\
\text { Age average: } 64.3\end{array}$ & NIHSS, mRS & $\begin{array}{l}\text { Arrival NSE of patients directly correlated } \\
\text { with the outcome of patients. }\end{array}$ \\
\hline Oh et $\mathrm{al}^{24}$ & All visiting patients for AIS check & $\begin{array}{l}\text { South Korea; } \\
\# \text { male: } 42, \# \text { female: } 39 \\
\text { Age average: } 66.7\end{array}$ & $\begin{array}{l}\text { Lesion volume in } \\
\text { MRI, NIHSS of the } \\
\text { seventh-day }\end{array}$ & $\begin{array}{l}\text { Serum NSE level had a direct correlation } \\
\text { with CVA volume and arrival NIHSS }\end{array}$ \\
\hline $\begin{array}{l}\text { Bharosay et } \\
\mathrm{al}^{25}\end{array}$ & $\begin{array}{l}251 \text { suspected patients of CVA that } \\
150 \text { of them suffering patients, and } \\
\text { the rest considered as the controlling } \\
\text { group. }\end{array}$ & $\begin{array}{l}\text { India; } \\
\# \text { male:95, \# female: } 55 \\
\text { Patients age: between } 35 \text { to } 85\end{array}$ & NIHSS & $\begin{array}{l}\text { In this study; Serum NSE level of the } \\
\text { severe group was higher than others }\end{array}$ \\
\hline Kaca et $\mathrm{al}^{26}$ & $\begin{array}{l}71 \text { patients suffering from AIS } \\
\text { included in the study, and } 41 \text { of them } \\
\text { considered as the controlling group }\end{array}$ & $\begin{array}{l}\text { Poland; } \\
\text { \# male: } 42, \# \text { female: } 29 \\
\text { Age average: } 71\end{array}$ & $\begin{array}{l}\text { NIHSS, Barther score, } \\
\text { mRS }\end{array}$ & $\begin{array}{l}\text { In this study; NSE with stroke volume and } \\
\text { patient's prognosis d not correlated. }\end{array}$ \\
\hline $\begin{array}{l}\text { Gonzalez et } \\
\mathrm{al}^{27}\end{array}$ & $\begin{array}{l}61 \text { hospitalized patients with ischemic } \\
\text { stroke diagnosis. }\end{array}$ & $\begin{array}{l}\text { Cuba; } \\
\text { \# male: } 33, \# \text { female: } 31 \\
\text { Age average: } 65.6\end{array}$ & NIHSS & $\begin{array}{l}\text { In this study; NSE correlated with } \\
\text { patients' prognosis }\end{array}$ \\
\hline Brea et $\mathrm{al}^{28}$ & $\begin{array}{l}224 \text { hospitalized patients with } \\
\text { ischemic stroke and hemorrhagic } \\
\text { diagnosis }\end{array}$ & $\begin{array}{l}\text { Spain; } \\
\text { \# male: } 114, \# \text { female: } 110 \\
\text { Age average: } 69.6\end{array}$ & NIHSS, mRS & $\begin{array}{l}\text { In this study; it determined that serum } \\
\text { NSE level in hemorrhagic patients is } \\
\text { higher and also its level is correlated } \\
\text { with ischemic and hemorrhagic patients } \\
\text { prognosis }\end{array}$ \\
\hline Singh et $\mathrm{al}^{16}$ & $\begin{array}{l}100 \text { patients suffering from CVA that } \\
\text { their NSE checked } 72 \text { hours later. }\end{array}$ & India & NIHSS & $\begin{array}{l}\text { In this study; serum NSE level was } \\
\text { correlated with NIHSS }\end{array}$ \\
\hline
\end{tabular}

Abbreviations: NSE, neuron-specific enolase; AIS, acute ischemic stroke; CVA, cerebrovascular accident; NIHSS, National Institutes of Health Stroke Scale; GCS, Glasgow coma scale; mRS, modified Rankin Scale.
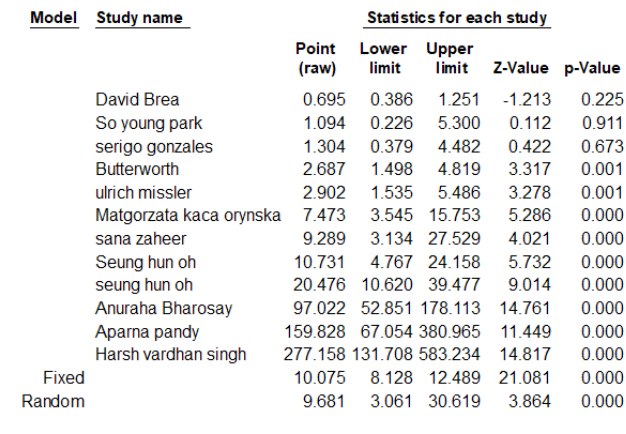

Point (raw) and $95 \% \mathrm{Cl}$

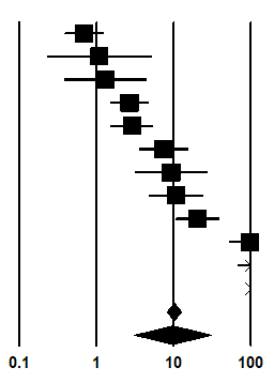

Figure 2. Forest Plot of the Odds Ratio of NSE in Stroke vs. Control CASES With 95\% CI Under the Fixed and Random Effect Models. 


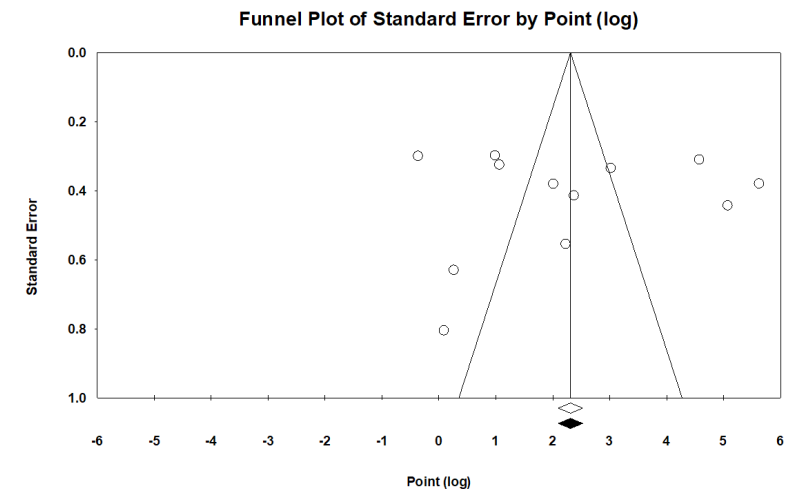

Figure 3. Funnel Plot of the Log (OR) of NSE in Stroke vs. Control Cases With The Standard Error of Under the Random Effect Model.

higher levels of NSE were associated with poor functional outcome in both acute ischemia and intracerebral hemorrhage patients. Pandey et $\mathrm{al}^{14}$ stratified stroke into different subtypes and showed that patients with hemorrhagic stroke had higher levels of NSE than patients with ischemic stroke. These results are supported by the results of Andersen et al ${ }^{37}$ who showed that NSE was more in patients with hemorrhagic stroke than infarct stroke.

\section{Strength Points}

The present meta-analysis demonstrated no heterogeneity regarding the significant effect of NSE on stroke between the included studies. The effect estimate was consistent under the fixed and random effects model. Additionally, the funnel plot method showed no evidence of publication bias. The trim and fill method gave the same effect estimate of meta-analysis, suggesting no small study effects, this indicates that our results are highly consistent and reliable.

\section{Limitations}

Study limitations come back to the variations between the included studies in defining the period of acute stroke, the measures of functional outcomes, the severity of stroke scales, and the methods of NSE concentrations. Also, 2 studies were excluded due to unreliable data extraction from them, as they reported the effect estimates in figures whose data could not be extracted and were unreliable for analysis.

\section{Conclusion}

Our results show higher levels of NSE in patients with stroke than in the control group, indicating that NSE plays a role in the diagnosis of stroke. In terms of prognosis, there is evidence regarding the direct and indirect relationship; and it founded that serum levels of NSE is higher in larger stroke volume, which needs further research.

\section{Conflict of Interest Disclosures}

The authors declare that they have no conflict of interests.

\section{Ethical Statement}

The study protocol approved by the University review board (IR. TUMS.MEDICINE.REC.1396.3905).

\section{Funding}

This study was conducted using a grant (35926-30-03-96) from Vice-Chancellor for Research, Tehran University of Medical Sciences.

\section{References}

1. Ohira T, Shahar E, Chambless LE, Rosamond WD, Mosley TH Jr, Folsom AR. Risk factors for ischemic stroke subtypes: the Atherosclerosis Risk in Communities study. Stroke. 2006;37(10):2493-8. doi: 10.1161/01. str.0000239694.19359.88.

2. Benjamin EJ, Blaha MJ, Chiuve SE, Cushman M, Das SR, Deo R, et al. Heart disease and stroke statistics-2017 update: a report from the American Heart Association. Circulation. 2017;135(10):e146-e603. doi: 10.1161/ cir.0000000000000485.

3. Baratloo A, Forouzanfar MM, Hashemi B, Safari S, Delavar Kasmaei $\mathrm{H}$, Rouhipour A, et al. Tissue plasminogen activator: A literature review. Arch Neurosci. 2016;3(1):e30452. doi: 10.5812/archneurosci.30452.

4. Delavar Kasmaei H, Baratloo A, Nasiri Z, Soleymani M, Oraee Yazdani M. Recombinant tissue plasminogen activator administration in patients with cerebrovascular accident; a case series. Arch Neurosci. 2015;2(2):e23315. doi: 10.5812/ archneurosci.23315.

5. Kidwell CS. MRI biomarkers in acute ischemic stroke: a conceptual framework and historical analysis. Stroke. 2013;44(2):570-8. doi: 10.1161/strokeaha.111.626093.

6. Leigh R, Krakauer JW. MRI-guided selection of patients for treatment of acute ischemic stroke. Curr Opin Neurol. 2014;27(4):425-33. doi: 10.1097/wco.0000000000000110.

7. Amans MR, Cooke DL, Vella M, Dowd CF, Halbach VV, Higashida RT, et al. Contrast staining on CT after DSA in ischemic stroke patients progresses to infarction and rarely hemorrhages. Interv Neuroradiol. 2014;20(1):106-15. doi: 10.15274/inr-2014-10016.

8. Mitomi M, Kimura K, Aoki J, Iguchi Y. Comparison of CT and DWI findings in ischemic stroke patients within 3 hours of onset. J Stroke Cerebrovasc Dis. 2014;23(1):37-42. doi: 10.1016/j.jstrokecerebrovasdis.2012.08.014.

9. Baratloo A, Rahimpour L, Abushouk AI, Safari S, Lee CW, Abdalvand A. Effects of telestroke on thrombolysis times and outcomes: a meta-analysis. Prehosp Emerg Care. 2018;22(4):472-84. doi: 10.1080/10903127.2017.1408728.

10. Haque A, Ray SK, Cox A, Banik NL. Neuron specific enolase: a promising therapeutic target in acute spinal cord injury. Metab Brain Dis. 2016;31(3):487-95. doi: 10.1007/s11011016-9801-6.

11. Kansal K, Irwin DJ. The use of cerebrospinal fluid and neuropathologic studies in neuropsychiatry practice and research. Psychiatr Clin North Am. 2015;38(2):309-22. doi: 10.1016/j.psc.2015.02.002.

12. Li K, Jia J, Wang Z, Zhang S. Elevated serum levels of NSE and S-100 $\beta$ correlate with increased risk of acute cerebral infarction in Asian populations. Med Sci Monit. 2015;21:187988. doi: 10.12659/MSM.893615

13. Zaheer S, Beg M, Rizvi I, Islam N, Ullah E, Akhtar N. Correlation between serum neuron specific enolase and functional neurological outcome in patients of acute ischemic stroke. Ann Indian Acad Neurol. 2013;16(4):504-8. doi: 10.4103/0972-2327.120442.

14. Pandey A, Shrivastava AK, Saxena K. Neuron specific enolase 
and c-reactive protein levels in stroke and its subtypes: correlation with degree of disability. Neurochem Res. 2014;39(8):1426-32. doi: 10.1007/s11064-014-1328-9.

15. Anand N, Stead LG. Neuron-specific enolase as a marker for acute ischemic stroke: a systematic review. Cerebrovasc Dis. 2005;20(4):213-9. doi: 10.1159/000087701.

16. Singh HV, Pandey A, Shrivastava AK, Raizada A, Singh SK, Singh N. Prognostic value of neuron specific enolase and IL-10 in ischemic stroke and its correlation with degree of neurological deficit. Clin Chim Acta. 2013;419:136-8. doi: 10.1016/j.cca.2013.02.014.

17. Lu K, Xu X, Cui S, Wang F, Zhang B, Zhao Y. Serum neuron specific enolase level as a predictor of prognosis in acute ischemic stroke patients after intravenous thrombolysis. J Neurol Sci. 2015;359(1-2):202-6. doi: 10.1016/j. jns.2015.10.034.

18. Moher D, Liberati A, Tetzlaff J, Altman DG. Preferred reporting items for systematic reviews and meta-analyses: the PRISMA statement. PLoS Med. 2009;6(7):e1000097. doi: 10.1371/ journal.pmed.1000097.

19. Stroup DF, Berlin JA, Morton SC, Olkin I, Williamson GD, Rennie D, et al. Meta-analysis of observational studies in epidemiology: a proposal for reporting. JAMA. 2000;283(15):2008-12. doi: 10.1001/jama.283.15.2008.

20. Borenstein M, Hedges LV, Higgins JPT, Rothstein HR. Introduction to meta-analysis. UK: John Wiley \& Sons Ltd; 2009.

21. Deeks JJ, Higgins JPT, Altman DG. Analysing data and undertaking meta-analyses. Cochrane Handbook for Systematic Reviews of Interventions: Cochrane Book Series; 2008:243-96. doi: 10.1002/9780470712184.ch9.

22. Hill MD, Jackowski G, Bayer $N$, Lawrence $M$, Jaeschke R. Biochemical markers in acute ischemic stroke. Cmaj. 2000;162(8):1139-40.

23. Oh SH, Lee JG, Na SJ, Park JH, Kim WJ. The effect of initial serum neuron-specific enolase level on clinical outcome in acute carotid artery territory infarction. Yonsei Med J. 2002;43(3):357-62. doi: 10.3349/ymj.2002.43.3.357.

24. Oh SH, Lee JG, Na SJ, Park JH, Choi YC, Kim WJ. Prediction of early clinical severity and extent of neuronal damage in anterior-circulation infarction using the initial serum neuronspecific enolase level. Arch Neurol. 2003;60(1):37-41.

25. Bharosay A, Bharosay VV, Varma M, Saxena K, Sodani A, Saxena R. Correlation of brain biomarker neuron specific enolase (NSE) with degree of disability and neurological worsening in cerebrovascular stroke. Indian J Clin Biochem. 2012;27(2):186-90. doi: 10.1007/s12291-011-0172-9.

26. Kaca-Orynska M, Tomasiuk R, Friedman A. Neuron-specific enolase and S 100B protein as predictors of outcome in ischaemic stroke. Neurol Neurochir Pol. 2010;44(5):459-63.

27. Gonzalez-Garcia S, Gonzalez-Quevedo A, Fernandez-
Concepcion O, Pena-Sanchez M, Menendez-Sainz C, Hernandez-Diaz Z, et al. Short-term prognostic value of serum neuron specific enolase and S100B in acute stroke patients. Clin Biochem. 2012;45(16-17):1302-7. doi: 10.1016/j. clinbiochem.2012.07.094

28. Brea D, Sobrino T, Blanco M, Cristobo I, Rodriguez-Gonzalez $R$, Rodriguez-Yanez $M$, et al. Temporal profile and clinical significance of serum neuron-specific enolase and S100 in ischemic and hemorrhagic stroke. Clin Chem Lab Med. 2009;47(12):1513-8. doi: 10.1515/cclm.2009.337.

29. Butterworth RJ, Wassif WS, Sherwood RA, Gerges A, Poyser $\mathrm{KH}$, Garthwaite J, et al. Serum neuron-specific enolase, carnosinase, and their ratio in acute stroke. An enzymatic test for predicting outcome? Stroke. 1996;27(11):2064-8.

30. Missler U, Wiesmann M, Friedrich C, Kaps M. S-100 protein and neuron-specific enolase concentrations in blood as indicators of infarction volume and prognosis in acute ischemic stroke. Stroke. 1997;28(10):1956-60.

31. Cunningham RT, Young IS, Winder J, O'Kane MJ, McKinstry $\mathrm{S}$, Johnston CF, et al. Serum neurone specific enolase (NSE) levels as an indicator of neuronal damage in patients with cerebral infarction. Eur J Clin Invest. 1991;21(5):497-500.

32. Wunderlich MT, Lins H, Skalej M, Wallesch CW, Goertler M. Neuron-specific enolase and tau protein as neurobiochemical markers of neuronal damage are related to early clinical course and long-term outcome in acute ischemic stroke. Clin Neurol Neurosurg. 2006;108(6):558-63. doi: 10.1016/j. clineuro.2005.12.006.

33. Ahmad O, Wardlaw J, Whiteley WN. Correlation of levels of neuronal and glial markers with radiological measures of infarct volume in ischaemic stroke: a systematic review. Cerebrovasc Dis. 2012;33(1):47-54. doi: 10.1159/000332810.

34. Park SY, Kim J, Kim OJ, Kim JK, Song J, Shin DA, et al. Predictive value of circulating interleukin- 6 and heart-type fatty acid binding protein for three months clinical outcome in acute cerebral infarction: multiple blood markers profiling study. Crit Care. 2013;17(2):R45. doi: 10.1186/cc12564.

35. Haiga Y, Amir D, Syafrita Y. Association between specific enolase serum levels and outcome acute ischemic stroke onset 1-month. Indonesian J Clinic Path Med Lab. 2019;25(2):1359. doi: 10.24293/ijcpml.v25i2.1377

36. Shahrokhi N, Soltani Z, Khaksari M, Karamouzian S, Mofid B, Asadikaram G. The serum changes of neuron-specific enolase and intercellular adhesion molecule-1 in patients with diffuse axonal injury following progesterone administration: a randomized clinical trial. Arch Trauma Res. 2016;5(3):e37005. doi: 10.5812/atr.37005.

37. Andersen KK, Olsen TS, Dehlendorff C, Kammersgaard LP. Hemorrhagic and ischemic strokes compared: stroke severity, mortality, and risk factors. Stroke. 2009;40(6):2068-72. doi: 10.1161/strokeaha.108.540112. 